\title{
Utopia e antropofagia na ficção de Darcy Ribeiro
}

\section{Utopia and anthropophagy in Darcy Ribeiro’s fiction}

\section{Marcelo Franz ${ }^{*}$ \\ Universidade de São Paulo}

Resumo: Este artigo quer entender na obra literária de Darcy Ribeiro as representações literárias de suas interpretações da identidade nacional na leitura de sua novela Utopia Selvagem: Saudades da Inocência Perdida (1982). Tomarei, eventualmente, como comparação a título de reforço para a tarefa de situação das ocorrências do livro de Darcy Ribeiro, dois importantes textos do modernismo da década de 20, Macunaíma (1928), de Mário de Andrade e Manifesto Antropófago (1928), de Oswald de Andrade. O norte teórico principal se fixará nas concepções formuladas pelo próprio Darcy Ribeiro em seus ensaios de antropologia e sociologia. Com isso talvez se possa discutir a ideia da formação de uma identidade nacional na literatura brasileira, com toda a sua complexidade e suas contradições, bem como a permanência e as transformações sofridas pelo debate sobre isso, levando em consideração a relevância conferida a esse problema pelos dois autores modernistas e por Darcy Ribeiro e a forma como elaboram, em épocas e sob impulsos ideológicos diferentes, os mitos fundantes de um suposto "ser brasileiro", fruto do choque e da síntese de antagonismos históricos e culturais.

Palavras-chave: Darcy Ribeiro. Ficção. Antropofagia.

\begin{abstract}
This article wants to understand in the literary work of Darcy Ribeiro the representations of his interpretations of national identity in the novel Utopia Selvagem: Saudades da Inocência Perdida (1982). I'll compare the occurrences of the Darcy Ribeiro's book, with two important texts of modernism of the 20s, Macunaíma (1928) of Mário de Andrade and Manifesto Antropofágico (1928) of Oswald de Andrade. The main theoretical north will be set in conceptions formulated by Darcy Ribeiro himself in his essays on anthropology and sociology. With this we can perhaps discuss the idea of forming a national identity in Brazilian literature, with all its complexity and contradictions, as well as continued and the transformations undergone by the debate about it, considering the importance given to this issue by two modernists and Darcy Ribeiro authors and the way they prepare, at different times and under different ideological impulses , the founding myths of a supposed "to be Brazilian", due to the shock and synthesis of historical and cultural antagonisms.
\end{abstract}

Keywords: Darcy Ribeiro. Fiction. Anthropophagy.

\author{
* Marcelo Franz \\ é professor de \\ literatura brasileira \\ e portuguesa da \\ PUCPR. Doutor em \\ Letras (Literatura \\ Portuguesa) pela \\ Universidade de São \\ Paulo - USP.marcelo. \\ franz@pucpr.br
}


Ainda está por ser feita uma compreensão crítica fina da porção literária da obra de Darcy Ribeiro, para além do envolvimento ideológico, da eventual identificação com as causas do autor - por ele defendidas com brilho e espírito civil notáveis - ou da recorrente estereotipação (quando não folclorização) da sua figura pessoal, colocada quase sempre numa plêiade de apaixonados quixotesco-macunaímicos que pensaram e viveram o ser brasileiro (o que quer que seja isso) sem meias medidas. Descontado o que haja de idealizado nesse seu perfil (que incluiria o intelectual out sider do sistema acadêmico e crítico da empostação vazia ali praticada, o militante político inflamado pela causa do nacional e até o sedutor de comportamento pessoal e relações de afeto expressas com linguagem corporal desinibida e autoconfiante), Darcy Ribeiro é uma das vozes mais interessantes, embora sem sempre bem compreendidas, que se fizeram ouvir “à esquerda” do pensamento brasileiro no século XX.

Sua marca mais nítida talvez seja a instabilidade estilística e conceitual, feita de uma certa rejeição do definitivo e da assunção de um projeto vivencial e epistemológico que não se queria aprisionado no formato de uma sentença-testemunho sobre a brasilidade, seu tema preferencial. Mais que isso, em sua irregularidade, sua obra declara amor ao que estuda. Isso é bom ou ruim?

Envolvida num projeto pessoal e intelectual “gauche”, sua obra é, no seu todo, tão vigorosa quanto errática no que busca com visível paixão. Nela reconhecemos importante contribuição para o pensamento latino-americano, presente no que Darcy escreveu sobre indígenas, europeus, negros e mestiços em involuntário (mas rico) processo de “amálgama” cultural e biotípico, responsável pela formação dos povos do continente. De todos estes, importa-lhe descrever mais de perto a formação do povo brasileiro, o que o leva a buscar uma teoria geral do Brasil e sua gente, intento que o motivou até seu estudo derradeiro, de 1995, que tem justamente esse título, síntese da sua curiosidade maior, O Povo Brasileiro.

No empenho de descrever esse povo se encontrou, desde os anos de formação - e aí está o seu diferencial intelectual em relação aos outros seus contemporâneos - não só com os textos de interpretação do Brasil já clássicos quando iniciou sua escrita (Retrato do Brasil (1928), de Paulo Prado, Raizes do Brasil (1936), de Sergio Buarque de Holanda, Casa Grande e Senzala (1933), de Gilberto Freyre), mas também com a experiência concreta do antropólogo de formação marxista que decidiu ser para entender o legado do indígena brasileiro para nossa cultura e, depois, com a experiência da militância política. Acrescento e esse diferencial uma outra experiência: a da incorporação do ideal estético modernista, assumido desde logo no discurso e na militância nacionalistas de uma escrita propositalmente livre do esquematismo (ou do beletrismo) acadêmico que se impôs como norma na nossa prática universitária desde 
a primeira metade do século $\mathrm{XX}$, um legado ruim entre outros bons da “iniciação ao saber” e da europeização metodológica pela qual a academia brasileira passou com a visita dos professores franceses à USP nos anos da sua fundação.

Se o intelectual Darcy Ribeiro não realiza em seus ensaios esse projeto modernista-pensador até o último limite em vista dos altos riscos a que exporia sua credibilidade científica (algo difícil de negociar, mesmo para um intelectual artista), ao menos antevê o imperativo de uma ruptura formal que só se completaria com a incorporação do discurso estético, na escrita, a partir dos anos de degredo forçado pela ditadura militar, de narrativas ficcionais motivadas pelo interesse de entender (às vezes mais do que de explicar) o Brasil.

Este artigo quer entender na obra literária de Darcy Ribeiro as representações literárias de suas interpretações da identidade nacional na leitura de sua novela Utopia Selvagem: Saudades da Inocência Perdida (1982) (a partir de agora referida neste estudo como Utopia Selvagem). Tomarei, eventualmente, como comparação a título de reforço para a tarefa de situação das ocorrências do livro de Darcy Ribeiro, dois importantes textos do modernismo da década de 20, Macunaíma (1928), de Mário de Andrade e Manifesto Antropófago (1928), de Oswald de Andrade. O norte teórico principal se fixará nas concepções formuladas pelo próprio Darcy Ribeiro em seus ensaios de antropologia e sociologia.

Com isso talvez se possa discutir a idéia da formação de uma identidade nacional na literatura brasileira, com toda a sua complexidade e suas contradições, bem como a permanência e as transformações sofridas pelo debate sobre isso, levando em consideração a relevância conferida a esse problema pelos dois autores modernistas e por Darcy Ribeiro e a forma como elaboram, em épocas e sob impulsos ideológicos diferentes, os mitos fundantes de um suposto "ser brasileiro", fruto do choque e da síntese de antagonismos históricos e culturais.

\section{O pensar “darciano" - elogio do mestiço}

Utopia Selvagem, escrita no começo dos anos 80, é uma novela alegórica e meio amalucada, movida por um arroubo de livre pensar de que o intelectual Darcy Ribeiro, no auge da sua maturidade de entendedor do Brasil, por certo se sentia merecedor. A alegoria ali desenhada, ambientada numa Amazônia fantástica, com grupos humanos em estado primitivo estabelecendo contato inamistoso e beligerante com a cultura do invasor civilizado - que, por sua vez, não tem outra reação diante do desconhecido e ameaçador do mundo novo que o aprisiona senão o medo (misturado a muito de encantamento) - remete a uma infinidade de registros, literários ou não, baseados na aproximação de culturas (algo em que a literatura brasileira é historicamente pródiga), com espaço eventual para o conflito e 
a assimilação. Na leitura vamos de citação em citação, de aproximação em aproximação e de paródia em paródia, de Thomas Morus a Jean-Jacques Rousseau, de Hans Satden a Mário de Andrade (de Macunaíma), de Montaigne a Shakespeare (de A tempestade, com as referências a Próspero e Caliban). Mas, no limite, a narrativa é sobre miscigenação e, como não poderia deixar de ser, sobre o Brasil e seus encontros culturais. Nisso o livro se comunica com outros textos sobre o assunto, possibilitando leituras paralelas e derivadas que ganham especial importância quando se leva em consideração os posiciomentos do pensador (mais do que do ficcionista) Darcy Ribeiro a respeito dessa matéria e seu modo de interagir com outros pareceres sobre a mestiçagem. Porém, mais do que isso, o texto se abre a uma sorte de "mestiçagem” discursiva, englobando e fazendo conviver, no plano da enunciação, diferentes registros e modos de proceder da linguagem (atendendo a diferentes intenções críticas) que completam e adensam a sua discussão sobre a pluralidade étnica ou o encontro de culturas na formação e no destino do brasileiro.

Assunto de importância fundamental nos estudos sobre o Brasil e sua formação cultural, a mestiçagem, entendida como fator decisivo da nossa identidade (ou do nosso destino) como povo, é um dos pontos mais discutidos e controversos do pensamento nacional, desde sempre. Superando as limitações epistemológicas e inadequações valorativas praticadas em inúmeros textos a esse respeito escritos sob o influxo racialista e determinista do final do século XIX, esse assunto ganha no século XX diferentes abordagens nas obras de alguns dos principais intérpretes da brasilidade, especialmente aqueles emergentes no período de afirmação de uma prática sociológica acadêmica moderna, não por acaso contemporânea da emergência de uma expressão literária que também se queria moderna e articulada em torno dos primados estéticos do modernismo e sua conhecida proposta de revisão do valor dado aos temas (e à linguagem literária) nacionais até então.

As diferentes abordagens resultam em valorações distintas para o fenômeno da miscigenação. Em Retrato do Brasil (1928), Paulo Prado, atuante também no movimento modernista de 1922, retrata o Brasil como o "reino da mestiçagem”, produto da “ebulição formidável do cadinho" em que se amalgamam todas as raças e que, no entanto, em virtude disso, não progride. Ocorre-lhe a comparação com o caso norte-americano e sua particular multirracialidade, na qual o puritanismo religioso e o instinto do trabalho e da colaboração coletiva trazidos pelos colonos ingleses, segregou o elemento africano. Segundo ele, aqui a luxúria e o desleixo social aproximaram e reuniram as raças. Prado cogita que é derivado desse fato, associado à construção de uma sociedade indefinida e marcada pelo primado dos interesses particularistas, que resulta o “povo triste”, melancólico, cansado e derrotado na busca de enriquecimento fácil (anseio e motivação básicos da colonização). Afirma o autor: "Na luta entre esses apetites - sem 
outro ideal, nem religioso, nem estético, sem nenhuma preocupação política, intelectual ou artística - criava-se uma raça triste” (PRADO, 1997, p. 106). Mas, a despeito da contundência deste retrato negativo, o objetivo da obra de Paulo Prado é uma prédica modernizante em que, por meio da constatação desses limites (que gerariam atitudes arcaicas nas lideranças nacionais, como o mandonismo e o bacharelismo), se propõe como solução uma sorte de "revolução".

Sérgio Buarque de Holanda, também remanescente de 1922, em Raízes do Brasil (1936) considera o legado da cultura ibérica, já mestiça quando do contato com a América, como a base da constituição da nossa sociedade. Nessa cultura, que tanto é a ponte entre Europa e os outros mundos como é a terra da "cultura da personalidade”, na qual os vínculos interpessoais são os mais decisivos, se fundamenta a construção das relações de poder no Brasil. Isso leva a uma estrutura social frouxa e à repulsa de toda moral fundada no culto ao trabalho. Tais valores foram acentuados e se adaptaram perfeitamente ao projeto econômico do latifúndio escravista.

É nesse Brasil rural e arcaico, de rígida estratificação social, que se sedimenta a família patriarcal, que, segundo o autor: "Fornecia a idéia mais normal do poder, da respeitabilidade, da obediência e da coesão entre os homens. O resultado era predominarem, em toda vida social, sentimentos próprios à comunidade doméstica, naturalmente particularista e antipolítica, uma invasão do público pelo privado, do Estado pela família” (HOLANDA, 1999, p. 143).

Decorre disso a escolha dos homens que irão exercer funções públicas pelo primado da confiança pessoal em detrimento das suas capacidades. Caracteriza-se nesse comportamento a célebre figura do "homem cordial”, cujas condutas se baseiam nas decisões do coração ou das preferências pessoais. A percepção final de Holanda é a de que o processo de urbanização do Brasil e a superação dos efeitos danosos desse legado ibérico (por meio de um processo revolucionário que teria se iniciado em 1888, com a abolição da escravatura) acabariam naturalmente com os fundamentos personalistas e aristocráticos da nossa sociedade. A miscigenação teria, portanto, papel, senão decisivo, ao menos destacado na construção dessa modernização aspirada.

Gilberto Freire, em Casa grande \& Senzala (1933) analisa a formação da sociedade colonial (patriarcal-agrária-escravocrata e monocultora) como o berço da nossa mestiçagem, a qual é vista positivamente, embora quase sempre se saliente essa positividade em vista do projeto colonial e o favorecimento das elites agrárias. A complexidade (ou o paradoxo) desse processo, que justapõe o horror da escravização à maravilha da criação de um povo mestiço e belo é assim descrita no livro: 
O que a monocultura latifundiária e escravocrata realizou no sentido da aristocratização, extremando a sociedade brasileira em senhores e escravos (...) foi em grande parte contrariado pelos efeitos sociais da miscigenação. A índia e a negra-mina a princípio, depois a mulata, a cabrosha, a quadradona, a oitavona, tornando-se caseiras, concubinas e até esposas legítimas dos senhores brancos, agiram poderosamente no sentido de democratização social no Brasil. (FREIRE, 1961, p. 7-8.).

Acrescenta que disso resulta o alastramento de traços africanos na constituição étnica do brasileiro médio: “Todo o brasileiro, mesmo o alvo, de cabelo louro, traz na alma, quando não na alma e no corpo - há muita gente de jenipapo ou mancha mongólica pelo Brasil - a sombra, ou pelo menos a pinta, do indígena ou do negro” (FREIRE, 1961, p. 12).

Freire constitui-se, assim, como difusor da ideologia da mestiçagem, do mito das três raças que se fundem em harmonia, caso único na América multirracial, já que no Brasil se verifica, pela mistura de raças, a convivência pacífica dos opostos. Esse fato acabaria por mitigar os conflitos sociais, o que é entendido pelo autor como uma tendência própria do nosso temperamento pois,

Considerada de modo geral, a formação brasileira tem sido (...) um processo de equilíbrio de antagonismos (...) predominando sobre todos os antagonismos, o mais geral e o mais profundo: o senhor e o escravo. É verdade que agindo sempre, entre tantos antagonismos contundentes, amortecendo-lhes o choque ou harmonizando-os condições de confraternização e de mobilidade social peculiares ao Brasil: a miscigenação. (FREIRE, 1961, p. 106).

Darcy Ribeiro, em seu livro-testamento, O Povo Brasileiro (1995), dá-se a um trabalho etnográfico semelhante ao de Sérgio Buarque de Holanda, desvendando as raízes étnicas e históricas de nossa identidade miscigenada. Atento à história brasileira, o autor descreve as circunstâncias da gênese do Brasil e do povo brasileiro. Salienta a elementar e primordial tríade multiétnica (portugueses, índios e negros) como a nossa base cultural. Segundo ele, origina-se do encontro desses três elementos raciais um povo novo que, em meio a crises de formação e adaptação física e cultural à realidade da miscigenação, faz surgir, um novo modelo de estruturação societária que inaugura uma forma singular de organização sócioeconômico, fundada num tipo renovado de escravismo e numa servidão continuada ao mercado mundial. Surge um novo gênero humano, marcado pela distinção cultural das três matrizes formadoras, mestiço (unificado nas diferenças, desprovido do sentido de segregação, o que não significa que não seja racista, por força dos efeitos da escravidão negra nas nossas atitudes e, sobretudo, nas nossas relações sociais), sincrético, propenso, apesar de tudo, à alegria. 
Mas o caráter conflitivo dessa miscigenação não é ignorado pela obra de Darcy Ribeiro, que considera como base formativa desse ser brasileiro, desapegado das matrizes originárias não mestiças, a constituição de uma série de negações (“desindianizando o índio, desafricanizando o africano, deseuropeizando o europeu”) responsáveis pela percepção final de uma alteridade crítica chamada pelo autor em outro se seus estudos - $O$ Brasil como problema (1995) - de "ninguendade”, que consiste na consciência de ser outro e, portanto, não ser ninguém. É isso o que o lhe permite afirmar:

Nós, brasileiros, somos um povo em ser, impedido de sê-lo. Um povo mestiço na carne e no espírito, já que aqui a mestiçagem jamais foi crime ou pecado. Nela fomos feitos e ainda continuamos nos fazendo. Essa massa de nativos viveu por séculos sem consciência de si. Assim foi até se definir como uma nova identida étnico-nacional, a de brasileiros. (RIBEIRO, 1995, p. 19).

Os recursos de que se vale a criação literária de Darcy Ribeiro são demarcados e decididos, tanto no imaginário ficcional por ele expresso como no discurso que o informa, pela experiência basilar do estudo antropológico. $\mathrm{O}$ diálogo que o ficcionista estabelece entre a ciência e a arte, é visível em muitos momentos de suas principais narrativas ficcionias (Maíra (1976), O Mulo (1981), Utopia Selvagem (1982), Migo (1988)), como exemplifica esse fragmento de Utopia Selvagem:

Releve o leitor que eu tome a palavra para algumas ponderações que não posso conter, tanto elas são cabíveis nesta altura. Do reconto das aventuras do ex-tenente ressalta, como fato mais novidadoso, a notícia de que as celebradas amazonas existem, continuam vivas e ativas. Quem, senão elas poderiam ser estas donas despeitadas que surgem no mesmo assinalado sítio, portando todos os signos delas?(...) Refiro-me à nossa primeira História. A que um certo PM Gandavo (...) fez imprimir em livro nos idos de 1576. (RIBEIRO, 1982. p. 134).

Oscilando entre o ensaístico e o literário, Utopia Selvagem é, a despeito do humor que a impulsiona, uma alucinação algo pessimista sobre o futuro do Brasil e da América Latina. É interessante recorrer aqui a uma explicação do próprio autor sobre o livro, reveladora de uma intenção eclética naquilo que busca tanto formal como conceitualmente:

Minha terceira novela Utopia Selvagem é uma espécie de fábula brincalhona, em que, parodiando textos clássicos e caricaturando posturas ideológicas, retrato o Brasil e a América Latina.(...) O melhor da minha Utopia é uma capítulo orwelliano, que desenha o mundo do futuro regido pelas multinacionais. Impagável. Gosto também do último capítulo, escrito para ser filmado por Glauber, sobre a alucinação coletiva de um povo indígena pala força da ayahuasca, que se chama também santo daime. Nas últimas 
páginas, a aldeia é uma ilha que sobrevoa o mundo e trava uma guerra contra o exército, a marinha e a aeronáutica, que atiram com seus canhões sobre ela. A aldeia inteira revida cagando na mão e jogando bosta nos miliCOS. (RIBEIRO, 1997, p. 34).

É sabido que de sua experiência como educador, antropólogo e político, Darcy Ribeiro trouxe para a escrita de suas narrativas a curiosidade sobre o tema do choque sempre presente quando do contato entre os universos do branco e do índio. Contudo, para além da visão dos universos potencialmente íntegros que se perdem (ou no mínimo entram em crise), importa à sua reflexão a mútua assimilação e a recíproca convocação à criação de um novo olhar (mestiço, brasileiro) sobre o mundo, sem desconsiderar também o drama dos seres que se separam das suas raízes culturais e buscam recuperar sua identidade.

Do ponto de vista literário, num exercício de liberdade que supera a seriedade no retrato dessa assimilação, visível, por exemplo, de Maíra (1976) (livro escrito no exílio no Peru e que se queria uma revisão sentida de sua vivência junto aos índios), Utopia Selvagem pende gostosamente para o cômico, num diálogo estilístico com os primados da linguagem literária e do temário modernista acrescido de umas pitadas das tônicas dominantes no pensamento tropicalista, especialmente na referência direta, em tom de homenagem, ao cinema de Glauber Rocha, num capítulo que teria sido escrito para ser filmado pelo cineasta do cinema novo e suas típicas leituras alegóricas da cultura brasileira.

Clara e elucidativa é esta sua declaração de apreço e reconhecimento da influência do Modernismo sobre sua obra, especialmente no retrato do Brasil feito pelo pensamento estético de Oswald de Andrade e sua noção de antropofagia cultural, assim analisada por Darcy Ribeiro em uma entrevista dada a Heloísa Buarque de Hollanda em 1983:

A Antropofagia do Oswald de Andrade era a expressão de um momento da literatura mundial e Oswald teve um talento formidável de devorar aquilo e dar uma linguagem para isso. Mas na realidade a antropofagia de Oswald é apenas uma promessa, de um vigor incrível, mas que nunca se completou como ato. Quem completa o ato é Mário de Andrade com Macunaíma, um livro definitivo, feito de erudição, um dos textos mais belos e mais dignos que o Brasil já teve. Foi um movimento de encontro conosco mesmo, contra o endeusamento do gramaticismo, do retoricismo, do helenismo, do francesismo de Bilac, do mundo gramatical de Rui Barbosa. A antropofagia é sempre importante porque expressa, dentro do Brasil, uma assunção do Brasil. (RIBEIRO in HOLLANDA, 1983, p.43).

As afinidades eletivas com esses referenciais estéticos, declaradas pelo autor e visíveis sem dificuldade por quem quer que leia o texto com atenção, ganham uma densidade maior quando se percebe o sentido 
conferido pela escrita de Darcy Ribeiro à prática literária da antropofagia (obviamente, para muito além da menção algo simplista ao canibalismo no livro). Oswaldianamente, seu texto se embrenha num universo de diálogos culturais e discursivos que acabam por configurar uma experiência antropofágica radical.

\section{Antropofagia e mestiçagem textual}

Se não for óbvio, creio ser oportuno recapitular algumas informações sobre a antropofagia, com o intuito, possivelmente válido, de aproximá-la ideologicamente das discussões sobre mestiçagem aludidas anteriormente. Em 1928, intuindo o fecho do ciclo polêmico dos debates de 1922 e do “Manifesto da Poesia Pau-Brasil”, Oswald de Andrade assume-se disposto a um radicalismo conceitual mais abrangente, que o leva à criação da $R e$ vista de Antropofagia, com a pretensão de restabelecer a linha revolucionária do Modernismo, não se restringindo apenas ao plano literário e muito menos ao social, político ou religioso, sendo tudo isso ao mesmo tempo.

De acordo com Maria Helena Junqueira, a antropofagia, tomada literalmente, tem sido considerada, ao longo da história da humanidade, um traço primitivo, marca definidora de certos estágios da evolução histórica e caracteriza aquele que se alimenta de seres de sua mesma espécie ou família. A antropofagia é vista como um momento mítico na estruturação e organização dos agrupamentos sociais. Sob a perspectiva oswaldiana, baseada numa compreensão positiva do ato ritualístico selvagem, a antropofagia representa uma transubstanciação na qual o devorador se altera pelo devorado, eventualmente de modo a "melhorar-se” (numa devoração crítica) se se aceitar que, via de regra, é à procura da "força” ou dos dotes elevados do inimigo que o antropófago está ao ingeri-lo. O conceito de “outro” se abre a algo além da oposição que enseja a eliminação, mesmo que haja o enfrentamento (JUNQUEIRA, 1994).

Assumida como postura literária, a antropofagia se mostra ao mundo na defesa dos pontos de vista de Oswald de Andrade no Manifesto Antropófago de 1928 e na composição da rapsódia de Mário de Andrade, Macunaíma (1926), no mesmo ano, embora, curiosamente, os dois não tenham mirado o mesmo alvo. Aparece como uma proposta de revisão da temática do nacional em face das forças culturais estrangeiras. Talvez a intenção ou a inspiração das iniciativas de Oswald de Andrade sejam já no seu nascedouro "insights” antropofágicos se pensarmos que a revista e o manifesto tiveram um precedente na vanguarda literária francesa, na revista Cannibale e no Manifeste Canniballe Dada, de Francis Picabia, ambos de 1920.

O conceito de antropofagia, do modo como imaginado pelo poeta, propõe, revolucionariamente, a reabilitação do primitivo no comportamento 
do homem civilizado, visando a restabelecer uma vitalidade talvez perdida, associada à atitude do mau selvagem numa suposta devoração da cultura alheia. Ressalte-se que essa postura, mesmo que incidentalmente (já que o universo indígena aludido no Manifesto é, sobretudo, simbólico), rivaliza com a tradição firmada desde o século XIX no tratamento do índio. Para a antropofagia oswaldiana, não há nem o Éden projetado pelas imagens românticas e exóticas nem as alegorias de origens mitológicas e símbolos que convertem o índio em ícone da monarquia e do nacionalismo. A atitude do índio reivindicada pelo artista moderno busca superar as dicotomias colonizador versus colonizado, civilizado versus bárbaro, natureza versus tecnologia. Segundo Leyla Perrone-Moisés: “A antropofagia é antes de tudo o desejo do "outro", a abertura e a recpetividade para o alheio, desembocando na recepção e na absorção da alteridade” (1990, p. 95).

Essa postura em relação ao “outro” e sua incorporação, na busca de um ir além do ressentimento ou da capitulação diante de nossa condição de povo colonizado é uma resposta a uma realidade perversa da cultura brasileira até aquele momento (que talvez nunca tenha sido apagada de todo, dada a sua complexidade como fenômeno histórico). Antonio Candido, afirma que, em virtude da situação do Brasil quando de seu surgimento, com as elites culturais que possuía, a imitação, era sinônimo de “integração” à cultura ocidental, da qual a nossa era um desdobramento pouco desenvolvido, que tomava os valores europeus como meta e modelo. Segundo Candido, o comportamento modernista diante desse problema haveria de propôr uma ruptura tanto em relação à servidão ao modelo estrangeiro (até onde fosse possível) como em relação à idealização de um nacionalismo algo artificial. Afirma Candido:

A ambigüidade fundamental da nossa cultura é proveniente do fato de que somos um povo 'latino', de herança cultural européia, mas etnicamente mestiço, situado no trópico, influenciado por culturas primitivas, ameríndi as e africanas. Esta ambigüidade deu sempre às afirmações particularistas um tom de constrangimento, que se resolvia pela idealização. (1976. p. 119).

Visto na evolução dos debates estéticos que o precederam, o Manifesto Antropófago amplia as idéias do Manifesto Pau-Brasil nos seguintes pontos: insistência radical no caráter indígena de nossas raízes: “Tupy or not tupy that is the question”; assunção do humor como forma crítica e traço distintivo do caráter brasileiro: “A alegria é a prova dos nove”; criação de uma utopia brasileira, centrada numa sociedade matriarcal, anárquica e sem repressões: “Contra a realidade social, vestida e opressora, cadastrada por Freud - a realidade sem complexos, sem loucura, sem prostituições e sem penitenciárias do matriarcado de Pindorama”.

É difícil que não se veja o desejo de realização de cada uma dessas propostas no que Darcy Ribeiro busca, mais de 50 anos depois de Oswald, 
em sua novela Utopia Selvagem. O enredo conta, inicialmente, a história dos infortúnios do ex-tenente Carvalhal, apelidado de Pitum e Orelhão, um brasileiro negro e gaúcho que se perde e se encontra no delírio da contrução/desconstrução de sua identidade cultural e nacional entre as índias Amazonas que o capturam na fronteira norte do Brasil. Elas são aproximadas explicitamente, desde o título do primeiro capítulo, à tribo das Icamiabas com a qual Macunaíma, na narrativa de Mário de Andrade, manteve contato - chegando à condição de imperador e entre elas, por causa de $\mathrm{Ci}$, decidindo o seu destino para sempre inconstante de procurar (sem jamais tocar de fato) a mesma identidade que inquieta Pitum. Chama a atenção o reflexo no comportamento belicista das índias tanto da idealização do "país mulheril" oswaldiano como a busca de incorporação dos dotes do "outro" (capturado para se prestar ao serviço de reprodutor involuntário, sujeito às ordens e ao desejo das guerreiras) na composição de uma descendência mestiça.

Na novela, a patente identificação com as idéias de Oswald de Andrade quanto à idealização/projeto do "país mulheril” e todo o seu sentido crítico é assim explicada por Gilberto Felisberto Vasconcellos:

(Darcy) é o Oswald de Andrade que conheceu de carne e osso a humanidade da selva selvagem (...). Tudo o que o escritor modernista consignou acerca do matriarcado Darcy Ribeiro reafirma com base em sua vivência. "As celebradas amazonas existem, continuam vivas e ativas”, escreve Darcy Ribeiro. Elas não tinham marido e casavam entre si. Foram "as primeiras revolucionárias da história”. Essas mulheres trotskistas, no dizer de Darcy Ribeiro, comiam a carne dos machos que matavam, sendo isso o ponto isso o ponto alto da celebração do matriarcado, expressão sociojurídica da “domesticação do milho e da mandioca. (2006. p. 21).

Mas essa leitura se amplia, compreendendo em paralelo com a descrição do perdido império “mulheril” oswaldiano a reflexão “darciana” dos problemas nacionais em virtude do contato com o dominador estrangeiro. Prossegue Vasconcellos:

O matriarcado foi rompido por uma contra-revolução machista de Jurupari, que seduziu e subjugou as mulheres. Aí se deu a hegemonia do macho, com a imposição das virtudes femininas: virgindade, fidelidade, frugalidade e discrição. A instituição da couvade, “comprobatória de que o importante na procriação é a paternidade, uma vez que a mulher é um mero saco em que o homem deposita sua semente", é o filho do direito paterno de que falava Oswald de Andrade a respeito da herança e da propriedade privada. Em Darcy Ribeiro, a dissolução do matriarcado trouxe a obediência da mulher ao marido, ao chefe, e o direito do homem à poligamia. (2006. p. 21).

Em Utopia Selvagem, Darcy Ribeiro justapõe o fim do matriarcado (e a perda da inocência) à afirmação da estrutura de poder multinacional, 
criando, ao final do livro, nas palavras de Gilberto Felisberto Vasconcellos, uma irônica utopia burguesa, com um "príncipe informático”, que programa seus súditos com um televisor "ecumênico no pulso e um canal fidebeque”. Segundo o crítico, é possível a seguinte decodificação da alegoria: “O sul do hemisfério está programado pelo Próspero colonizador com dominação multinacional e televisionária. Os gerentes das multinacionais cumprem os deveres do setor predominante da classe dominante nativa” (RIBEIRO, 1982, p.21). Em muitos sentidos, na reverência prestada à matriz ideológica oswaldiana, Darcy Ribeiro propõe um debate sobre questões (sempre) atuais relativas à complexa relação do Brasil com o dominador estrangeiro em termos econômicos e culturais, na qual ocorrem a submissão e o servilismo.

O combate a isso se configura, no ideário do autor, como luta pela construção de uma identidade nacional cuja base seria a assunção de nossa mestiçagem (atributo diferenciador altamente positivo), tomada como princípio de unificação também do povo latino-americano. Mas a novela, quanto a isso, nos oferece uma visão complexa do entendimento do autor, colocando lado a lado a visão etnocêntrica do europeu (apresentada quase sempre num elaborado e irônico discurso indireto livre) e a visão da ideologia pró-miscigenação, compatível com a que, na qualidade de antropólogo, Darcy Ribeiro sempre assumiu. Numa interessante seqüência digressiva de tom ensaístico do texto, o narrador, usando de uma personificação voltada aos interesses da metalinguagem (por assumir e revelar o processo de escrita) tece esta reflexão sobre a mestiçagem:

Nosso enigma é muitíssimo mais complicado. Começa com a tenebrosa invasão civilizadora. Mil povos únicos, saídos virgens da mão do Criador, com suas mil caras e falas próprias, são dissolvidos no tacho com milhões de pituns, para fundar a Nova Roma Multitudinária. Uma Galibia Neolatina tão grande como assombrada de si mesma. Inexplicável. Aqueles tontos povos singelos que aqui eram já intrigaram demais ao descobridor e seus teólogos:

- Gentes são ou são bichos racionais? Têm alma capaz de culpa? Podem comungar? O enxame de mestiços que deles devieram na mais prodigiosa misturação de raças intriga ainda mais (...)

- Quem somos nós? Nós mesmos? Eles? Ninguém?

Acordando como nações no meio desta balbúrdia, nos perguntamos com o Libertador:

- Quem somos nós, se não somos europeus, nem somos índios, senão uma espécie intermediária, entre aborígenes e espanhóis?

Somos os que fomos desfeitos no que éramos, sem jamais chegar a ser o que formos ou quiséramos. Não sabendo quem éramos quando demorávamos inocentes neles, inscientes de nós, menos sabemos quem seremos.

(...) Os povos sem história que cá éramos frente aos façanhudos que de lá 
vieram naquela hora sumiram ou confluíram e trocaram de ser. (RIBEIRO, 1982. p.32).

Há uma mudança no tom dessa discussão quando, do aparente questionamento da mestiçagem se passa para o elogio dela. O narrador, numa digressão agora opinativa a respeito da posição do protagonista Pitum como "macho prenhador” capturado pelas índias da tribo das Amazonas imagina que em sua "pena”, o ex-tenente deveria era estar feliz,

porque vai gerar - está gerando - uma mulataria de guerreiras cafusas, fogosas e bravas de dar gosto. Acho até que Pitum gostaria desta vida se soubesse que podia durar, vivendo anos aqui, para criar suas filhas todas e depois, as netas, filhas delas. Às vezes até sonhará com isto. (RIBEIRO, 1982, p.66).

A mestiçagem, de resto, já é pressuposta na caracterização das próprias guerreiras Icamiabas, uma vez que elas são o resultado mestiço de cruzamentos étnicos através do rapto de homens de outras “tribos”, para exercer a mesma função que exerceu Pitum.

No complexo das idéias de Utopia Selvagem, e de todo o pensamento de Darcy Ribeiro, persiste a compreensão da miscigenação como o fator preponderante na definição do caráter do povo brasileiro a ponto de não se imaginar a possibilidade de haver geração futura em nosso país se os três elementos básicos de nossa constituição, o negro, o branco e o índio, permanecessem isolados, sem se cruzarem.

Do mesmo modo, a suposição de um texto linear, autocentrado (autônomo numa única experiência discursiva) e não dialógico para a expressão de um enredo sobre o Brasil miscigenado e sua complexidade cultural seria algo impensável, sobretudo para um discípulo de Oswald de Andrade como é Darcy Ribeiro. É recorrente no proceder narrativo de Darcy uma situação emblemática desse encontro (antropofágico) de usos de linguagem que marca algumas das mais fortes características formais dos seus textos narrativos: a voz narrativa freqüentemente suspende o fluxo narrativo, propondo, como personagem, debates e comentários num tom ensaístico que é consoante com o estilo (e também com o complexo temático) de sua prosa científica.

O ensaísmo a que me refiro é a forma textual híbrida (ou mestiça) descrita por Massaud Moisés em seu estudo A criação literária (1997). Trata-se do ensaio cujo modelo é firmado no século XVI pela obra de Michel de Montaigne e que se caracteriza formalmente pela discussão livre de um tema sobre o qual se faz uma cogitação (marcada por ponderação, retórica elegante e envolvente) cujo tom oscila entre o objetivo e o subjetivo, sendo que é na subjetivação do eu que fala que por vezes esse tipo de ensaio toca o literário. Contudo, a exposição do eu numa atitude 
pensante é até mais incisiva do que a que se vê na experiência literária. Se nas formas ficcionais o narrador (ou mesmo o autor) pode-se esconder atrás da malha verbal, de modo que a voz que ecoa na obra não é a de seu criador como tal, o ensaio caracteriza-se pelo desnudamento sincero de quem se dispõe a empregá-lo como forma de expressão. O ensaísta é aquele que tem consciência aguda do relativo em que vive imerso como ser humano e como inteligência analítica. É nesse espaço subjetivo/objetivo, dividido entre os atributos da voz narrativa com a incumbência de contar a história e o labor investigativo e opinativo do estudioso (que, de resto, é o mesmo dos textos científicos) que se coloca, “nutrindo-se” de tudo o que lhe interesse para a composição do texto, que se coloca o escritor Darcy Ribeiro naquilo que se propõe a escrever em sua novela. Mas considero necessário, do ponto de vista crítico, levar em conta uns pontos de relativização do valor dessa aliança entre arte e o pensamento.

Embora as fronteiras entre essas formas de expressão tenham-se tornado virtuais em inúmeras criações modernas, com a proliferação de artistas-pensadores e de filósofos-romancistas desde meados do século passado, é conceitualmente problemática a comunhão das duas coisas sem a diminuição de uma delas. A arte do século XX foi melhor e mais rica sempre que conseguiu essa difícil comunhão, sem se eximir do debate ideológico e sem negligenciar as suas atribuições de criação artística. Nesse ponto, há que se notar o fato de ser a elaboração material do produto, o modo de se proceder o constructo, na melhor arte deste tempo, o veículo por excelência das idéias. Em suma, o objeto da discussão idéias vem e deve vir pressuposto preferencialmente na materialidade formal do que o informa. Sem uma expressão formal adequada, trabalhada de modo criativo e livre, qualquer arte se perde, porque a imposição ou prevalência do ideológico pressupõe fronteiras, limites, que por vezes se evidenciam no respeito a dados “compromissos". No extremo, o comprometimento empobrece a arte, porque a aproxima do "utilitarismo” que é contrário ao que é essencialmente estético.

Saliente-se que Darcy Ribeiro pouco se inquietava com os riscos que corria com esse hibridismo do discurso, que o encaminhou, voluntariamente, a uma sorte de ensaísmo (à la Montaigne, mas com a consciência da auto-ironia) caracterizável como “mestiço” devido às indefinições de caráter a que ele está relacionado, que alia um discurso ensaístico impuro a um discurso narrativo por vezes desfigurado, numa experiência criativa antropofágica, dando-se ao que Moacir Werneck de Castro define no texto de apresentação do livro como "uma utopia à brasileira, que ao contrário de suas congêneres contemporâneas do mundo desenvolvido, geralmente sombrias, quando não sinistras, irradia otimismo, esperança, alegria criadora. Uma anti-utopia, de raízes antropofágicas, vivida por testemunhas do impossível” (RIBEIRO, 1982) mesmo que seu autor tenha acreditado na possibilidade da sua realização. 


\section{Referências}

ANDRADE, Mário. Macunaíma, o herói sem nenhum Caráter. Belo Horizonte/Rio de Janeiro, Livraria Garnier, 31 ed. 2000.

CANDIDO, Antonio. Literatura e Sociedade. São Paulo, Editora Naiconal, 5 ed. 1976.

CUNHA, Eneida Leal. A Antropofagia, antes e depois de Oswald. In: TELLES, Gilberto M. et.al. Oswald Plural, Rio de Janeiro: UERJ, 1995.

FREYRE, Gilberto. Casa Grande \& Senzala: formação da família brasileira sob o regime da economia patriarcal. Rio de Janeiro, José Olympio, 1961.

HOLANDA, Sérgio Buarque de. Raízes do Brasil. São Paulo, Companhia das Letras, 1999.

HOLLANDA, Heloísa Buarque de. Darcy Ribeiro A Utopia do Intelectual Indignado In: Folha de São Paulo, 01/10/1983, p. 43.

JUNQUEIRA, Maria Helena. Canibalismo e Cultura. In: ECO: Publicação da Pós-graduação em Comunicação e Cultura da Escola de Comunicação da UFRJ. V.1. n.5 Rio de Janeiro: Imago Editora, 1994.

MOISÉS, Massaud. A criação literária. 15. ed. São Paulo: Cultrix, 1997. PERRONE-MOISÉS, Leyla. Literatura Comparada, intertexto e antropofagia. In: Flores na escrivaninha. São Paulo: Companhia das Letras, 1990.

PRADO, Paulo. Retrato do Brasil: ensaio sobre a tristeza brasileira. São Paulo, Cia. das Letras, 1997.

RIBEIRO, Darcy. Maíra. Rio de Janeiro, Civilização Brasileira, Rio de Janeiro, 1976.

- Utopia Selvagem: Saudades da Inocência Perdida. Rio de Janeiro, Record, 1982.

. O Brasil como problema. Rio de Janeiro, Francisco Alves,1995.

1995.

O Povo Brasileiro. $2^{\circ}$.ed., São Paulo, Companhia das Letras,

. Confissões. São Paulo, Companhia das Letras, 1997.

VASCONCELLOS, Gilberto Felisberto. Darcy Ribeiro, ignoto deo na antropologia do novo mundo. In: Caros Amigos. Ano IX, n. 106, Janeiro de 2006.

Recebido em 20/11/2013

Aprovado em 05/02/2014 